\title{
Soil Genesis of Four Alfisols Established in Oak Hickory Forests along Drainages into the Mississippi River in Southeastern Missouri, USA
}

\author{
Michael Aide \\ Southeast Missouri State University, Cape Girardeau, MO, USA \\ Email:mtaide@semo.edu
}

How to cite this paper: Aide, M. (2021). Soil Genesis of Four Alfisols Established in Oak Hickory Forests along Drainages into the Mississippi River in Southeastern Missouri, USA. Journal of Geoscience and Environment Protection, 9, 124-143. https://doi.org/10.4236/gep.2021.92008

Received: January 19, 2021

Accepted: February 17, 2021

Published: February 20, 2021

Copyright $\odot 2021$ by author(s) and Scientific Research Publishing Inc. This work is licensed under the Creative Commons Attribution International License (CC BY 4.0).

http://creativecommons.org/licenses/by/4.0/

\begin{abstract}
Alfisols in USA taxonomy are "deciduous forest" soils having an argillic horizon with a base saturation in the control section greater than $35 \%$. Alfisols are geographically extensive and support productive agriculture and deciduous forest ecosystems. Understanding Alfisol genesis, including the presence and intensity of the dominant soil processes, facilitates best management practices that provide stewardship for these soil resources and improves forest and agriculture productivity. Four Alfisols, presently having mature forest settings and located in the central United States along the Mississippi River, were selected for soil and landscape description, classification, and delineation of the dominant soil forming processes. Excavated soils were described and routinely sampled for subsequent physical, chemical, and mineralogical analysis. An aqua regia digestion protocol provided elemental analysis for identifying and inferring the intensity of soil forming processes. The dominant soil forming factors include 1) organic matter accumulation, 2) clay eluviation-illuviation, 3) acidification, 4) base cation accumulation in the A horizons by the forest vegetation, 5) Fe-oxyhydroxide formation, and 6) clay mineral synthesis. Two soils were developed entirely in Peoria loess and two soils were developed in Peoria Loess overlying Ordovician limestone residuum. Ecological site descriptions provide land managers information for evaluating land suitability and the capability to implement different management activities without ecosystem disturbance. Best management practices for the described landforms and based on their Ecological Site Descriptions are presented.
\end{abstract}

\section{Keywords}

Alfisols, Deciduous Forests, Peoria Loess, Clay Mineralogy, Ecological Site Description 


\section{Introduction}

Alfisols are a soil order in USA "Keys of Soil Taxonomy" (Soil Survey Staff, 2014). Alfisols are typically developed under mixed forests in temperate climates that maintain a low to moderate level of soil organic matter, a neutral to acidic $\mathrm{pH}$ and have a moderate degree of base saturation. One requirement of Alfisols is the presence of an argillic horizon, coupled with the requirement of having a base saturation greater than $35 \%$ in the argillic horizon control section. The argillic horizon is a subsurface B horizon having at least 1.2 times more clay than some horizon above it, or 3\% more clay if the eluvial layer has less than $15 \%$ clay or $8 \%$ more clay if the eluvial layer has more than $40 \%$ clay (Soil Survey Staff, 2014). The argillic horizon is formed by the illuviation of clay and this horizon usually has clay coatings on ped faces or clay bridges among the sand grains (Soil Survey Staff, 2014). Missouri Alfisols usually have udic moisture regimes and support deciduous forest vegetation (Buol et al., 2003).

In the USA, an emerging Federal governmental program is to develop ecological site descriptions (ESD's) for all the Major Land Resource Areas (MLRA's). Ecological site descriptions are management size appropriate land areas that have specific landscapes that have similar climatic attributes, soils, landforms and physiographic features, hydrology, and a defined terrestrial plant community and associated wildlife, that when viewed holistically provide basic ecological information for conservation planning and land management

[https://www.nrcs.usda.gov/wps/portal/nrcs/detail/national/landuse/rangepastur e/?cid=stelprdb1068392].

An Ecological Site is a distinctive landscape having specific qualities and attributes that produce a distinctive kind and abundance of vegetation and biological diversity. The marriage of Ecological Site Descriptions with soil survey provides a holistic inventory of information required to support landowners in making land management decisions. The landowner will understand the vegetational and wildlife diversity implications of their land management decisions, such that land stewardship becomes knowledge based.

The manuscript's purpose is to investigate two forested study areas to: 1) determine the soil morphology and chemical-physical characteristics of the dominant soils (Alfisols) and isolate the soil forming factors important to soil genesis, and 2) demonstrate the applications for best land use as described from the Ecological Sites Descriptions.

\section{Materials and Methods}

\subsection{Study Area}

Two study areas in Cape Girardeau County (Missouri) are included in this manuscript: 1) the Juden Creek Conservation Area and 2) the Apple Creek Conservation Area, each area having a western mesophytic forest and located adjacent to the Mississippi River. These sites were selected because they have minimal human impact, and the soils are broadly representative of the region. The cli- 
mate is humid continental. The Juden Creek Conservation area landscape consists of steep-sided drainages and narrow ridges with the forest vegetation consisting of various oak species (Quercus), hickory species (Carya) and American Beech (Fagus grandifolia). The drainages provide runoff water directly to the floodplain of the Mississippi River.

Two sampled pedons of the Menfro series (Fine-silty, mixed, superactive, mesic Typic Hapludalfs) are developed in thick (more than 8 meters) of Peoria Loess overlying Ordovician carbonate rocks. The two sampled Menfro pedons are very deep, well drained, moderately permeable soils on upland ridgetops. The pedons exhibit A-E-BE-Bt-BC-C horizon sequences having ochric epipedons $(\mathrm{A}, \mathrm{E}$, and $\mathrm{BE})$ overlying a thick argillic $(\mathrm{Bt})$ horizon. No evidence of mass wasting was evident adjacent to the sampled pedons.

The Apple Creek Conservation Area largely consists of steep sided drainages caused by downcutting of the uplands that drain into a bottomland landscape. The upland vegetation is dominated by a mixed forest, primarily composed of various species of Oak (Quercus) and Hickory (Carya). The underlying lithology is Paleozoic carbonate rocks ranging from the Ordovician to the Devonian. The sampled upland pedons of the Apple Creek Conservation Area are from soils of the Alred and Rueter series.

The Alred series (loamy-skeletal over clayey, siliceous, semiactive, mesic Typic Paleudalfs) and the Rueter series (loamy-skeletal, siliceous, active, mesic Typic Paleudalfs) present very deep A-E-2Bt horizon sequences (Ochric-Argillic). The well-drained Alred series consists of cherty hillslope sediments and underlying clayey residuum, whereas the somewhat excessively well-drained Rueter series formed in colluvium and/or residuum from cherty limestone. Both pedons in the Apple Creek Conservation Area are suspected to have some incorporation of Peoria Loess in their near-surface horizons.

The defined Ecological Site Description (ESD) for the Juden Creek Conservation Area containing the two Menfro pedons is the Deep Loess Upland Woodland (F115BY001MO) that borders the Deep Loess Protected Backslope Forest (F115BY003MO). The ESD specifies that the: 1) primary vegetation is tree (Quercus rubra, Quercus alba), shrub (Asimina triloba) and herbaceous (Laportea canadensis, Erigenia bulbosa), 2) landforms are deeply dissected, loess covered hills, 3) underlying bedrock is Ordovician-aged dolomite, and (4) specified climatic and hydrology features and soil types are specified. Other ESD's within the study area are based on aspect, slope position, and soil thickness to bedrock.

The defined Ecological Site Description for the Apple Creek Conservation Area containing the Alred and Rueter pedons is the Chert Protected Backslope Forest (F115BY011MO) that borders the Loamy Upland Woodland (F115BY005MO). The ESD specifies that the: 1) primary vegetation is tree (Quercus alba, Quercus rubra), shrub (Cornus florida) and herbaceous (Polystrichum acrostichoides, Podophyllum peltatum), 2) landforms are deeply dissected, loess covered hills, 3) underlying bedrock is Ordovician-aged dolomite, and 4) specified climatic and 
hydrology features and soil types are specified. Other ESD's within the study area are based on aspect, slope position, and soil thickness to bedrock.

\subsection{Methodology}

Four pedons were located, described, and sampled according to Soil Survey Division Staff (1993) in undisturbed forest settings using excavated pits. Personnel of the United States Department of Agriculture-Natural Resources Conservation Service performed the soil profile descriptions.

Samples were oven dried, lightly crushed, and sieved to remove materials larger than $2 \mathrm{~mm}$. Soil $\mathrm{pH}$ using equal volumes of soil and water, the $\mathrm{NH}_{4}$-acetate ( $\mathrm{pH}$ 7.0) extraction of exchangeable bases, the total acidity by slow titration to $\mathrm{pH}$ 8.2, and soil organic matter (SOM) by loss on ignition were performed using standard methods (Carter, 1993). The two $\mathrm{M}$ acetic acid extractable $\mathrm{SO}_{4}-\mathrm{S}$ and Bray-1 phosphorus soil test analyses were performed by the soil testing laboratory at the University Missouri Delta Center (Portageville, MO). The particle size distribution (mechanical analysis) was determined by Na-saturation of the exchange complex, dispersion in $\mathrm{Na}_{2} \mathrm{CO}_{3}$ (pH 9.0) and centrifuge fractionated to remove clay followed by wet sieving of the silt and sand separates. The sand separate was subdivided by dry sieving into very fine $(0.1$ to $0.05 \mathrm{~mm})$, fine $(0.25$ to $0.1 \mathrm{~mm})$, medium ( 0.5 to $0.25 \mathrm{~mm}$ ), coarse (1 to $0.5 \mathrm{~mm}$ ), and very course (2 to $1 \mathrm{~mm}$ ) sub-separates (Carter, 1993).

An aqua-regia digestion was employed to obtain a near total estimation of elemental abundance associated with all but the most recalcitrant soil chemical environments. Aqua-regia does not appreciably degrade quartz, albite, orthoclase, anatase, barite, monazite, sphene, chromite, ilmenite, rutile and cassiterite, whereas aqua-regia partially degrades anorthite and phyllosilicates (Aide and Fasnacht, 2010). Homogenized samples $(0.75 \mathrm{~g})$ were equilibrated with 0.01 liter of aqua-regia (3 volumes $\mathrm{HNO}_{3}$ to 1 volume $\mathrm{HCl}$ ) in a $35^{\circ} \mathrm{C}$ incubator for 24 hours. Duplicated samples were shaken, centrifuged, and filtered $(0.45 \mu \mathrm{m})$, with a known aliquot volume analyzed using inductively coupled plasma mass spectrometry (ICP-MS). Reference samples with known elemental concentrations were employed for quality control.

Oriented whole clay $(<2 \mu \mathrm{m})$ samples were prepared for X-ray diffraction. Magnesium-saturated and glycerol-solvated samples were air-dried on glass-slides, producing oriented mounts (Moore and Reynolds, 1989). X-ray diffractograms were obtained with a Scintag diffractometer using $\mathrm{CuKa}$ radiation $(45 \mathrm{kv}$ and 40 ma). Spectra were scanned from $2^{\circ}$ to $30^{\circ} 2 \theta$ at $0.02^{\circ} \mathrm{s}^{-1}$. Peak areas were used to compare clay mineral differences among soil horizons. Peak areas were determined after background removal and were calculated from the product of peak height and half-height peak width. Peak positions of 1.77 to $1.8 \mathrm{~nm}, 1.4$ to 1.5 $\mathrm{nm}, 0.99$ to $1.01 \mathrm{~nm}$, and 0.71 to $0.72 \mathrm{~nm}$ were used to identify smectite, hydroxy-Al interlayered vermiculite, clay mica and kaolinite, respectively (Moore and Reynolds, 1989). 


\section{Results}

\subsection{The Menfro Pedons Located in the Juden Creek Conservation Area}

The well-drained Menfro pedons are entirely developed in Peoria Loess, exhibiting A-E-BE-Bt-BC-C horizon sequences. Both pedons are on ridge-top landscape positions. The soil texture is predominately silt loam, except for the silty clay loam textures of the Bt4 and Bt5 horizons of pedon \#1 (Table 1). The A horizons have weak fine granular (spherical) structures, whereas the argillic horizons exhibit moderate medium prismatic structures that part to moderate fine and medium subangular block structures. Soil colors in Menfro pedon \#1 range from dark brown to brown in the eluvial horizons to uniformly dark yellowish-brown colors in the argillic horizon. The Menfro pedon \#2 colors range from very dark grayish brown in the A horizon to dark yellowish brown in the argillic horizons. Clay films are nearly continuous in the middle portions of the argillic horizons of pedon \#1, corresponding with a greater clay content (Table 2). The clay films in the Menfro pedon \#2 are continuous to patchy. Silt flows in

Table 1. Soil morphology for two soils of the Menfro series.

\begin{tabular}{|c|c|c|c|c|c|c|}
\hline Horizon & $\begin{array}{c}\text { Depth } \\
\mathrm{cm}\end{array}$ & Texture & Structure & Boundary & Color & Roots \\
\hline A & 10 & sil & $1 \mathrm{fgr}$ & aw & $10 \mathrm{YR} 3 / 3$ & many $f \& \mathrm{~m}$ \\
\hline $\mathrm{E}$ & 20 & sil & $1 \mathrm{fsbk}$ & $\mathrm{cW}$ & $10 \mathrm{YR} 4 / 3$ & common $\mathrm{f} \& \mathrm{~m}$ \\
\hline $\mathrm{BE}$ & 28 & sil & $2 \mathrm{f} \& \mathrm{~m} \mathrm{sbk}$ & cs & $10 Y R 5 / 4$ & common $\mathrm{f} \& \mathrm{~m}$ \\
\hline Bt1 & 46 & sil & $2 \mathrm{f} \& \mathrm{~m} \mathrm{sbk}$ & cs & $10 \mathrm{YR} 4 / 6$ & few $f \& m$ \\
\hline $\mathrm{Bt} 2$ & 66 & sil & $2 \mathrm{f} \& \mathrm{~m} \mathrm{sbk}$ & $\mathrm{cs}$ & $10 \mathrm{YR} 4 / 6$ & few $m$ \\
\hline Bt3 & 84 & sil & $2 \mathrm{f} \& \mathrm{~m} \mathrm{sbk}$ & cs & $10 \mathrm{YR} 4 / 4$ & few $m$ \\
\hline Bt4 & 104 & sicl & $2 \mathrm{~m} \mathrm{sbk}$ & cs & $10 \mathrm{YR} 4 / 6$ & \\
\hline $\mathrm{Bt} 5$ & 137 & sicl & $2 \mathrm{~m} \mathrm{sbk}$ & cs & 10YR4/6 & \\
\hline $\mathrm{BC}$ & 170 & sil & $2 \mathrm{f} \& \mathrm{~m} \mathrm{sbk}$ & & $10 Y R 5 / 4$ & \\
\hline A & 5 & sil & $2 \mathrm{fgr}$ & as & $10 \mathrm{YR} 3 / 2$ & many $\mathrm{f} \& \mathrm{~m}$ \\
\hline $\mathrm{E}$ & 23 & sil & $2 \mathrm{vf} / \mathrm{fsbk}$ & cs & $10 Y R 3 / 4$ & common $\mathrm{f} \& \mathrm{~m}$ \\
\hline $\mathrm{BE}$ & 43 & sil & $1 \mathrm{fsbk}$ & cs & $10 \mathrm{YR} 4 / 6$ & common $\mathrm{f} \& \mathrm{~m}$ \\
\hline Bt1 & 58 & sil & $2 \mathrm{msbk}$ & cs & $10 \mathrm{YR} 4 / 6$ & few $f \& m$ \\
\hline $\mathrm{Bt} 2$ & 81 & sil & $2 \mathrm{f} / \mathrm{msbk}$ & cs & $10 \mathrm{YR} 4 / 4$ & few $m$ \\
\hline $\mathrm{Bt} 3$ & 114 & sil & $2 \mathrm{f} / \mathrm{msbk}$ & cs & $10 \mathrm{YR} 4 / 4$ & few $m$ \\
\hline Bt4 & 135 & sil & $2 \mathrm{f} / \mathrm{msbk}$ & cs & $10 \mathrm{YR} 4 / 4$ & \\
\hline $\mathrm{Bt} 5$ & 163 & sil & $2 \mathrm{f} / \mathrm{msbk}$ & cs & 10YR4/4 & \\
\hline BC & 191 & sil & massive & & $10 Y R 4 / 4$ & \\
\hline
\end{tabular}

Texture: sil is slit loam, sicl is silty clay loam; Boundary: aw is abrupt wavy, cs is clear smooth; Sturcture: $1=$ weak, 2 = moderate, $\mathrm{f}=$ fine, $\mathrm{m}=$ medium; Structure: $\mathrm{gr}=$ spherical, sbk = subangular blocky; Roots: $\mathrm{f}$ is fine, $\mathrm{m}$ is medium; Note: Bt3 exhibited nearly continuous clay films; Note: common silt flows in Bt4 to Bt5 (10YR7/1 and 7/2). 
Table 2. Particles size distribution.

\begin{tabular}{|c|c|c|c|}
\hline Horizon & sand percent & silt percent & clay percent \\
\hline A & 25 & 66 & 9 \\
\hline $\mathrm{E}$ & 18 & 72 & 10 \\
\hline $\mathrm{BE}$ & 18 & 78 & 4 \\
\hline Bt1 & 13 & 73 & 14 \\
\hline Bt2 & 15 & 60 & 25 \\
\hline Bt3 & 10 & 63 & 27 \\
\hline Bt4 & 10 & 60 & 30 \\
\hline Bt5 & 9 & 62 & 29 \\
\hline $\mathrm{BC}$ & 8 & 68 & 24 \\
\hline A & 36 & 58 & 6 \\
\hline $\mathrm{E}$ & 20 & 71 & 9 \\
\hline $\mathrm{BE}$ & 24 & 67 & 9 \\
\hline Bt1 & 16 & 73 & 11 \\
\hline Bt2 & 14 & 74 & 12 \\
\hline Bt3 & 18 & 68 & 14 \\
\hline Bt4 & 13 & 71 & 16 \\
\hline Bt5 & 15 & 71 & 14 \\
\hline $\mathrm{BC}$ & 12 & 73 & 15 \\
\hline
\end{tabular}

the lower portions of the argillic horizons have grayish (10YR7/1 and 7/2) colors, suggesting silt dispersion because of Fe-oxyhydroxide depletion.

The $\mathrm{pH}$ of the Menfro A horizons is slightly acidic, whereas the $\mathrm{pH}$ of the argillic horizons ranges from strongly acidic to very strongly acidic in pedon \#1 and strongly acidic in pedon \#2 (Table 3(a)). Calcium is the dominant exchangeable cation, followed by magnesium, potassium and sodium is present in very minor concentrations. The base saturation in the A horizons exceeds $90 \%$ and the base saturation in the argillic horizons ranges from $40 \%$ to $63 \%$, reflecting the $\mathrm{pH}$ distribution. The cation exchange capacity is low (less than $12 \mathrm{cmol} \cdot \mathrm{kg}^{-1}$ ) to medium (12 to $18 \mathrm{cmol} \cdot \mathrm{kg}^{-1}$ ). The soil organic matter content is $4.2 \%$ for pedon \#1 and 8.3\% in pedon \#2 for the A horizons. Both the Bray-1 extractable $\mathrm{P}$ and $2 \mathrm{M} \mathrm{KCl}$ extractable $\mathrm{SO}_{4}-\mathrm{S}$ concentrations have maximum expression in the A horizons and diminish with increasing soil profile depth. The clay mineralogy in the eluvial horizons is mixed, composed of hydroxy-Al interlayered vermiculite and kaolinite, with secondary abundances of hydrous mica (formerly termed Illite). The clay mineralogy in the illuvial horizons is mixed, composed of hydroxy- $\mathrm{Al}$ interlayered vermiculite and kaolinite, with secondary abundances of smectite and hydrous mica.

The aqua regia digestion was performed to assess the near total elemental content, by soil horizon. The aqua regia digestion of $\mathrm{P}$ and $\mathrm{S}$ (Table $3(\mathrm{~b})$ ) shows a 
Table 3. (a) Routine soil chemical characterization for two soils of the Menfro series; (b) Chemical Characterization of the Menfro series.

(a)

\begin{tabular}{|c|c|c|c|c|c|c|c|c|c|}
\hline \multirow[t]{2}{*}{ Horizon } & \multirow[t]{2}{*}{$\mathrm{pH}$} & $\begin{array}{c}\mathrm{KCl} \\
\text { Acidity }\end{array}$ & $\begin{array}{c}\text { Total } \\
\text { Acidity }\end{array}$ & $\mathrm{Ca}$ & $\mathrm{Mg}$ & $\mathrm{K}$ & $\mathrm{Na}$ & CEC & \multirow{2}{*}{$\begin{array}{l}\text { Base Sat } \\
\text { percent }\end{array}$} \\
\hline & & \multicolumn{7}{|c|}{$\mathrm{cmol} / \mathrm{kg}$} & \\
\hline A & 6.3 & 0.17 & 0.25 & 6.7 & 1.4 & 0.51 & 0.12 & 9 & 97 \\
\hline $\mathrm{E}$ & 5.2 & 0.48 & 1.56 & 2.7 & 0.8 & 0.24 & 0.07 & 5.4 & 71 \\
\hline $\mathrm{BE}$ & 4.7 & 1.09 & 2.28 & 2 & 0.5 & 0.19 & 0.08 & 5.1 & 54 \\
\hline Bt1 & 4.6 & 1.64 & 3.39 & 1.5 & 0.6 & 0.21 & 0.07 & 5.8 & 41 \\
\hline Bt2 & 4.5 & 2.47 & 5.14 & 2.2 & 1.2 & 0.31 & 0.1 & 9 & 42 \\
\hline Bt3 & 4.5 & 2.78 & 5.32 & 2.7 & 2.8 & 0.48 & 0.11 & 11.4 & 53 \\
\hline Bt4 & 4.4 & 2.62 & 6.77 & 2.8 & 4.2 & 0.41 & 0.15 & 14.3 & 53 \\
\hline Bt5 & 4.3 & 1.04 & 5.02 & 3.3 & 4.8 & 0.37 & 0.2 & 13.7 & 63 \\
\hline $\mathrm{BC}$ & 4.5 & 1.11 & 3.27 & 4.9 & 5.3 & 0.34 & 0.4 & 14.2 & 77 \\
\hline A & 6.9 & 0.11 & 0.5 & 12.4 & 2.1 & 0.49 & 0.1 & 15.6 & 97 \\
\hline $\mathrm{E}$ & 6.4 & 0.07 & 0.57 & 6.1 & 1.1 & 0.29 & 0.11 & 8.2 & 93 \\
\hline $\mathrm{BE}$ & 4.9 & 0.56 & 3.2 & 4.2 & 1.5 & 0.28 & 0.11 & 9.3 & 65 \\
\hline Bt1 & 4.6 & 2.28 & 4.1 & 3.9 & 1.8 & 0.38 & 0.12 & 10.3 & 60 \\
\hline Bt2 & 4.6 & 2.34 & 5.19 & 3.1 & 2.3 & 0.38 & 0.11 & 11.1 & 53 \\
\hline Bt3 & 4.5 & 2.1 & 4.37 & 2.7 & 3 & 0.41 & 0.14 & 10.6 & 59 \\
\hline Bt4 & 4.4 & 1.68 & 6.44 & 2.9 & 3.1 & 0.35 & 0.14 & 12.9 & 50 \\
\hline Bt5 & 4.6 & 2.49 & 6.5 & 4.8 & 3.9 & 0.35 & 0.23 & 15.8 & 59 \\
\hline $\mathrm{BC}$ & 4.6 & 0.9 & 5.49 & 5.6 & 4.3 & 0.39 & 0.3 & 16.1 & 66 \\
\hline
\end{tabular}

Total Acidity is total acidity, $\mathrm{KCl}$ acidity is $\mathrm{KCl}$ extractable acidity, $\mathrm{SOM}$ is soil organic matter; $\mathrm{Ca}, \mathrm{Mg}, \mathrm{K}$, $\mathrm{Na}$ is ammonium acetate ( $\mathrm{pH}$ 7) extraction; $\mathrm{CEC}$ is cation exchange capacity, Base Sat is base saturation.

(b)

\begin{tabular}{cccccc}
\hline Horizon & $\begin{array}{c}\text { SOM } \\
\text { percent }\end{array}$ & $\begin{array}{c}\text { P } \\
\text { Bray-1 } \\
\mathbf{m g} / \mathbf{k g}\end{array}$ & $\begin{array}{c}\mathbf{S} \\
\mathbf{M ~ K C l} \\
\mathbf{m g} / \mathbf{k g}\end{array}$ & $\begin{array}{c}\mathbf{P} \\
\mathrm{AR} \\
\mathbf{m g} / \mathbf{k g}\end{array}$ & $\begin{array}{c}\mathrm{S} \\
\mathrm{AR} \\
\mathbf{m g} / \mathbf{k g}\end{array}$ \\
\hline A & 4.2 & 37 & 4 & 440 & 290 \\
E & 1.8 & 23 & 2 & 310 & 140 \\
BE & 1.3 & 19 & 3 & 340 & 80 \\
Bt1 & 1.1 & 22 & 2 & 220 & 60 \\
Bt2 & 1.3 & 31 & 8 & 220 & 60 \\
Bt3 & 1.6 & 36 & 5 & 220 & 60 \\
Bt4 & 1.7 & 14 & 5 & 210 & 50 \\
Bt5 & 0.9 & 12 & 4 & 200 & 60 \\
BC & 1 & 20 & 3 & 200 & 50 \\
A & 8.3 & 32 & 5 & 430 & 290 \\
\hline
\end{tabular}


Continued

\begin{tabular}{cccccc}
\hline E & 3 & 14 & 3 & 430 & 100 \\
BE & 1.3 & 24 & 1 & 340 & 70 \\
Bt1 & 1.2 & 32 & 2 & 360 & 60 \\
Bt2 & 1.4 & 36 & 3 & 350 & 60 \\
Bt3 & 1.5 & 32 & 4 & 330 & 60 \\
Bt4 & 1.4 & 25 & 4 & 310 & 60 \\
Bt5 & 1.2 & 26 & 4 & 320 & 50 \\
BC & 1 & 26 & 7 & 310 & 50 \\
\hline
\end{tabular}

$\mathrm{P}$ Bray-1 is phosphorus extraction, $2 \mathrm{M} \mathrm{KCl}$ is the sulfate extraction; $\mathrm{AR}$ is an aqua regia digestion.

maximum in the A horizons with a smaller and relatively uniform distribution with soil profile depth. The corresponding Bray-1 $\mathrm{P}$ for $\mathrm{H}_{2} \mathrm{PO}_{4}$ values and the 2 $\mathrm{M} \mathrm{KCl}$ extraction for $\mathrm{SO}_{4}$-S values are much smaller than those of the aqua regia digestion and their soil profile distribution is uniform. The soil organic matter contents do not show significant correlation with Bray- $1 \mathrm{P}$ and $\mathrm{P}$ aqua regia digestion values, whereas the soil organic matter content correlation with the aqua regia digestion for sulfur $(r=0.89)$ values is significant. Both $\mathrm{P}$ and $\mathrm{S}$ have an appreciable affinity for Fe-oxyhydroxide adsorption or occlusion.

The aqua regia digestion of important alkali and alkaline earth elements show significant correlation with clay content: $\mathrm{K}(\mathrm{r}=0.96$ for Menfro pedon \# 1 and $\mathrm{r}$ $=0.86$ for Menfro pedon \#2), $\mathrm{Mg}(\mathrm{r}=0.93$ for Menfro pedon \# 1 and $\mathrm{r}=0.91$ for Menfro pedon \#2), whereas calcium is not significantly correlated with clay content (Table 4). Lithium, $\mathrm{Rb}$, and $\mathrm{Cs}$ show similar trends to $\mathrm{K}$ with respect to clay content and $\mathrm{Sr}$ and $\mathrm{Ba}$ show similar trends to $\mathrm{Mg}$ with respect to clay content (data not shown). Given that the aqua regia digestion $\mathrm{K}$ and $\mathrm{Mg}$ concentrations are much greater than the $\mathrm{K}$ and $\mathrm{Mg}$ exchangeable cation concentrations, most of these elements are associated as lattice constituents of phyllosilicates and primary minerals that are only marginally digested by the aqua regia digestion protocol.

The aqua regia digestion iron concentrations range from 9300 to 26,500 $\mathrm{mg} \cdot \mathrm{kg}^{-1}$ for the Menfro pedon \#1 and range from 9800 to $25,400 \mathrm{mg} \cdot \mathrm{kg}^{-1}$ for the Menfro pedon \#2 (Table 5). For the combined Menfro pedons the aqua regia digestion iron content is significantly correlated with the clay content $(r=0.91)$. Iron is presumed to be primarily adsorbed as Fe oxyhydroxides onto external clay surfaces and is also occluded with $\mathrm{Al}$ in the clay interlayer positions. Aqua regia digestion iron concentrations demonstrated a significant correlation with aqua regia digested aluminum $(\mathrm{r}=0.98)$, reflecting the prospect that the recovered aluminum and iron were largely associated with degraded phyllosilicates. For the combined Menfro pedons, the clay content is significantly correlated with the aqua regia digested recoveries for $\mathrm{Ni}(\mathrm{r}=0.92), \mathrm{Cu}(\mathrm{r}=0.90)$, and $\mathrm{Zn}(\mathrm{r}$ $=0.80$ ). The Mn aqua regia digestion concentrations exhibit a maximum in the A horizons, suggesting forest and understory biocycling. 
Table 4. Aqua regia digestion of alkali and alkaline earth metals from the Menfro series.

\begin{tabular}{|c|c|c|c|c|}
\hline \multirow{2}{*}{ Horizon } & $\mathrm{Na}$ & $\mathrm{K}$ & $\mathrm{Mg}$ & $\mathrm{Ca}$ \\
\hline & \multicolumn{4}{|c|}{$\mathrm{mg} / \mathrm{kg}$} \\
\hline A & 120 & 900 & 1300 & 2000 \\
\hline $\mathrm{E}$ & 110 & 700 & 1200 & 600 \\
\hline $\mathrm{BE}$ & 110 & 700 & 700 & 200 \\
\hline Bt1 & 130 & 900 & 1500 & 500 \\
\hline Bt2 & 170 & 1400 & 2300 & 1300 \\
\hline $\mathrm{Bt} 3$ & 180 & 1900 & 3400 & 500 \\
\hline $\mathrm{Bt} 4$ & 180 & 2000 & 4000 & 500 \\
\hline Bt5 & 190 & 1900 & 3900 & 700 \\
\hline BC & 230 & 1700 & 3900 & 1200 \\
\hline A & 130 & 100 & 1500 & 4000 \\
\hline $\mathrm{E}$ & 120 & 800 & 1200 & 1500 \\
\hline $\mathrm{BE}$ & 140 & 1200 & 2200 & 1000 \\
\hline Bt1 & 130 & 1800 & 3200 & 700 \\
\hline Bt2 & 130 & 1800 & 3300 & 400 \\
\hline Bt3 & 190 & 2200 & 4000 & 500 \\
\hline Bt4 & 190 & 2000 & 4100 & 700 \\
\hline Bt5 & 200 & 1900 & 3900 & 900 \\
\hline $\mathrm{BC}$ & 240 & 2100 & 4100 & 1200 \\
\hline
\end{tabular}

Table 5. Aqua regia digestion of aluminum and selected transition metals.

\begin{tabular}{|c|c|c|c|c|c|c|c|}
\hline \multirow{2}{*}{ Horizon } & $\mathrm{Al}$ & $\mathrm{Fe}$ & Mn & Co & $\mathrm{Ni}$ & $\mathrm{Cu}$ & $\mathrm{Zn}$ \\
\hline & \multicolumn{7}{|c|}{$\mathrm{mg} / \mathrm{kg}$} \\
\hline A & 7300 & 9300 & 1040 & 7.8 & 12.7 & 7.19 & 57.7 \\
\hline E & 7200 & 9800 & 619 & 7.3 & 10.4 & 6.15 & 35.3 \\
\hline $\mathrm{BE}$ & 7500 & 10,400 & 484 & 6.9 & 10.3 & 6.39 & 30 \\
\hline Bt1 & 9900 & 12,400 & 482 & 7.4 & 12.4 & 7.98 & 37.3 \\
\hline Bt2 & 15,600 & 18,300 & 373 & 10.3 & 17.2 & 12.1 & 52.4 \\
\hline Bt3 & 22,000 & 24,000 & 403 & 8.7 & 22 & 17.8 & 75.4 \\
\hline Bt4 & 22,100 & 26,500 & 483 & 9.2 & 23.1 & 19.4 & 73 \\
\hline Bt5 & 21,000 & 25,600 & 410 & 7.3 & 22.1 & 20 & 71.2 \\
\hline $\mathrm{BC}$ & 18,200 & 23,400 & 682 & 9.2 & 23.5 & 20.8 & 78.3 \\
\hline A & 8800 & 10,100 & 1260 & 7.4 & 14.9 & 8.33 & 61.8 \\
\hline $\mathrm{E}$ & 8000 & 9800 & 1180 & 7.1 & 13.2 & 6.39 & 46.5 \\
\hline $\mathrm{BE}$ & 14,900 & 17,200 & 539 & 11.1 & 18 & 11.9 & 58.7 \\
\hline Bt1 & 21,600 & 23,500 & 417 & 8.1 & 21.5 & 17.3 & 69.4 \\
\hline
\end{tabular}


Continued

\begin{tabular}{llllllll}
\hline Bt2 & 19,700 & 21,800 & 497 & 8.6 & 19.3 & 17.3 & 66.7 \\
Bt3 & 22,900 & 25,400 & 567 & 8.8 & 23.9 & 20.5 & 79.8 \\
Bt4 & 20,500 & 25,400 & 718 & 11.6 & 23.6 & 20.3 & 79.5 \\
Bt5 & 18,600 & 23,500 & 624 & 8.5 & 22.9 & 18.6 & 71.8 \\
BC & 20,600 & 24,000 & 482 & 7.2 & 24 & 18.8 & 81.7 \\
\hline
\end{tabular}

\subsection{The Alred and Rueter Pedons Located in the Apple Creep Conservation Area}

The extremely gravelly and cobbly Alred pedon (loamy-skeletal over clayey, siliceous, semiactive, mesic Typic Paleudalfs) was a very deep, well-drained soil formed in cherty hillslope sediments and clayey residuum, presumably derived from the weathering of Paleozoic carbonate rocks. The Alred pedon was located on a gently sloping convex landscape position. The pedon has a silt loam ochric epipedon and an albic subsurface horizon overlying a clayey argillic horizon, thus displaying an A-E-2Bt horizon sequence. Moderate fine subangular blocky structures in the near surface horizons transition to moderate fine subangular and angular blocky structures in the 2Bt horizons (Table 6). The dominant soil matrix colors are very dark grayish brown and yellowish brown, and brown in the A, E1 and E2 horizons, transitioning to yellowish red in the 2Bt horizons. The near surface horizons have an abundance of fine and very fine roots, whereas the deeper argillic horizon has less than one percent very fine root expression. The particle size distribution for the Alred pedon demonstrates 10 to $45 \%$ cherty gravel and cobbles. The argillic horizon has a clayey texture, whereas the eluvial horizons have silt loam textures. The abrupt and substantial increase in the clay content on transition from the eluvial to illuvial horizons resulted in the placement of a lithologic discontinuity (Table 7).

Soil $\mathrm{pH}$ ranges from slightly acidic and acidic in the near-surface horizons to acid and very strongly acid throughout the argillic horizon (Table 8(a)). The soil organic matter contents are generally moderate and decline with increasing soil depth (Table $8(\mathrm{~b})$ ). The exchangeable cations are dominated by calcium (Ca), especially in the deeper soil horizons. The total acidity is appreciable, particularly in the deeper soil horizons. The CEC is low (less than $12 \mathrm{cmol} \cdot \mathrm{kg}^{-1}$ ) in the eluvial horizons and high (more than $18 \mathrm{cmol} \cdot \mathrm{kg}^{-1}$ ) in the argillic horizon and the CEC distribution throughout the soil profile corresponds with the soil profile's clay content.

The extremely gravelly and cobbly Rueter pedon (loamy-skeletal, siliceous, active, mesic Typic Paleudalfs) is a very deep, somewhat excessively-drained soil formed in colluvium and residuum derived from the weathering of Paleozoic carbonate rocks. The Rueter pedon was located on a sloping landscape position. A thin loess mantle is suspected to comprise the ochric epipedon and is present to a significant extent the argillic horizon, contributing to the rather uniform silt loam texture of the A-E-Bt1-2Bt2-2Bt3 horizon sequence. The Rueter pedon has 
Table 6. Soil morphology for the Alred and Reuter Series.

\begin{tabular}{|c|c|c|c|c|c|c|c|}
\hline Horizon & $\begin{array}{l}\text { Depth } \\
\text { cm }\end{array}$ & Texture & $\begin{array}{c}\text { Fragments } \\
\%\end{array}$ & Structure & Boundary & Color & Roots \\
\hline \multicolumn{8}{|l|}{ Alred } \\
\hline A & 10 & sil & 20 & $2 \mathrm{vf} g r$ & $\mathrm{cs}$ & 10YR3/2 & common $\mathrm{f} \& \mathrm{vf}$ \\
\hline E1 & 35 & sil & 33 & $2 \mathrm{f} \mathrm{sbk}$ & gw & 10YR5/4 & few $f \&$ vf \\
\hline E2 & 49 & sil & 45 & $2 f \& m$ & gw & 7.5YR5/4 & few $f \&$ vf \\
\hline $2 \mathrm{Bt} 1$ & 66 & clay & 35 & $2 \mathrm{f} \& \mathrm{~m}$ & gw & 5YR4/6 & trace $\mathrm{f}$ \\
\hline $2 \mathrm{Bt} 2$ & 92 & clay & 20 & $2 \mathrm{fabk}$ & gw & 5YR4/6 & trace $\mathrm{f}$ \\
\hline $2 \mathrm{Bt} 3$ & 106 & clay & 25 & $2 \mathrm{fabk}$ & gw & $5 Y R 4 / 6$ & trace vf \\
\hline $2 \mathrm{Bt} 4$ & 124 & clay & 10 & $2 \mathrm{fabk}$ & & 5YR4/6 & trace vf \\
\hline \multicolumn{8}{|l|}{ Rueter } \\
\hline A & 6 & sil & 20 & $1 \mathrm{f} \mathrm{sbk}$ & as & 10YR4/3 & common $\mathrm{f} \& \mathrm{vf}$ \\
\hline $\mathrm{E}$ & 32 & sil & 20 & $2 \mathrm{f} \mathrm{sbk}$ & aw & 10YR6/3 & common $\mathrm{f} \& \mathrm{vf}$ \\
\hline Bt1 & 70 & sil & 37 & $2 \mathrm{f} \mathrm{sbk}$ & $\mathrm{cw}$ & 10YR5/6 & few $f \& v f$ \\
\hline $2 \mathrm{Bt} 2$ & 96 & sil & 70 & $1 \mathrm{f} \mathrm{sbk}$ & gw & $7.5 \mathrm{YR} 4 / 6$ & trace $\mathrm{f}$ \\
\hline $2 \mathrm{Bt} 3$ & 143 & sil & 70 & $1 \mathrm{f} \mathrm{sbk}$ & & 5YR5/8 & trace $\mathrm{f}$ \\
\hline
\end{tabular}

Texture: sil is silt loam; Structure: 1 is weak, 2 is moderate, vf is very fine, $\mathrm{f}$ is fine, $\mathrm{gr}$ is spherical, sbk is subangular blocky, abk is angular blocky; Boundary: a is abrupt, $\mathrm{c}$ is clear, $\mathrm{g}$ is gradual, $\mathrm{s}$ is smooth, $\mathrm{w}$ is wavy; Roots: $f$ is fine, $v f$ is very fine.

Table 7. Particle size distribution.

\begin{tabular}{cccc}
\hline \multirow{2}{*}{ Horizon } & Sand & Silt & Clay \\
\cline { 2 - 4 } Alred & & percent & \\
A & 44 & 53 & 3 \\
E1 & 24 & 69 & 7 \\
E2 & 24 & 60 & 16 \\
2Bt1 & 15 & 23 & 62 \\
2Bt2 & 14 & 19 & 67 \\
2Bt3 & 5 & 24 & 71 \\
2Bt4 & 4 & 26 & 71 \\
Rueter & & & 4 \\
A & 32 & 64 & 4 \\
E & 21 & 75 & 14 \\
Bt1 & 15 & 71 & 29 \\
$2 B t 2$ & 14 & 57 & 22 \\
$2 B t 3$ & 24 & 54 & \\
\hline
\end{tabular}


Table 8. (a) Routine soil chemical characterization for the Alred and Rueter soils; (b) Chemical characterization of Alred and Rueter Soils.

(a)

\begin{tabular}{|c|c|c|c|c|c|c|c|c|}
\hline \multirow{2}{*}{ Horizon } & \multirow{2}{*}{$\mathrm{pH}$} & Total Acidity & $\mathrm{Ca}$ & $\mathrm{Mg}$ & $\mathrm{K}$ & $\mathrm{Na}$ & CEC & \multirow{2}{*}{$\begin{array}{l}\text { Base Sat } \\
\text { percent }\end{array}$} \\
\hline & & \multicolumn{6}{|c|}{$\mathrm{cmol} / \mathrm{kg}$} & \\
\hline \multicolumn{9}{|l|}{ Alred } \\
\hline A & 6.4 & 2.5 & 7.4 & 1.1 & 0.28 & 0.01 & 11.3 & 78 \\
\hline E1 & 5.5 & 3.8 & 2.3 & 0.6 & 0.18 & 0.01 & 6.9 & 47 \\
\hline E2 & 5.1 & 4.5 & 2.8 & 0.09 & 0.18 & 0.03 & 8.4 & 63 \\
\hline $2 \mathrm{Bt} 1$ & 5 & 14.5 & 9.7 & 2.7 & 0.46 & 0.07 & 24.4 & 73 \\
\hline $2 \mathrm{Bt} 2$ & 5.1 & 10.5 & 13.7 & 3.7 & 0.47 & 0.08 & 28.4 & 85 \\
\hline $2 \mathrm{Bt} 3$ & 4.9 & 7 & 14.7 & 3.9 & 0.49 & 0.15 & 26.3 & 47 \\
\hline $2 \mathrm{Bt} 4$ & 4.9 & 3.5 & 15.7 & 4 & 0.42 & 0.11 & 23.7 & 46 \\
\hline \multicolumn{9}{|l|}{ Rueter } \\
\hline A & 5.5 & 3.6 & 3.5 & 0.7 & 0.36 & 0.01 & 8.2 & 57 \\
\hline $\mathrm{E}$ & 5.1 & 1.7 & 1.1 & 0.3 & 0.26 & 0.03 & 3.4 & 53 \\
\hline Bt1 & 4.6 & 2.8 & 1.4 & 0.8 & 0.43 & 0.08 & 5.5 & 52 \\
\hline $2 \mathrm{Bt} 2$ & 4.2 & 7.1 & 3.3 & 2.2 & 0.32 & 0.08 & 13 & 46 \\
\hline $2 \mathrm{Bt} 3$ & 5.3 & 3.3 & 5 & 2.1 & 0.07 & 0.07 & 10.5 & 70 \\
\hline
\end{tabular}

SOM is soil organic matter; $\mathrm{Ca}, \mathrm{Mg}, \mathrm{K}, \mathrm{Na}$ is ammonium acetate ( $\mathrm{pH}$ 7) extraction; CEC is cation exchange capacity; Base Sat is base saturation.

(b)

\begin{tabular}{|c|c|c|c|c|c|}
\hline \multirow[t]{2}{*}{ Horizon } & \multirow{2}{*}{$\begin{array}{c}\text { SOM } \\
\text { percent }\end{array}$} & $\begin{array}{c}\text { P } \\
\text { Bray-1 }\end{array}$ & $\begin{array}{c}\mathrm{S} \\
2 \mathrm{M} \mathrm{KCl}\end{array}$ & $\begin{array}{c}\mathrm{P} \\
\mathrm{AR}\end{array}$ & $\begin{array}{c}S \\
A R\end{array}$ \\
\hline & & $\mathrm{mg} / \mathrm{kg}$ & $\mathrm{mg} / \mathrm{kg}$ & $\mathrm{mg} / \mathrm{kg}$ & $\mathrm{mg} / \mathrm{kg}$ \\
\hline \multicolumn{6}{|l|}{ Alred } \\
\hline A & 7.8 & 41 & 66 & 280 & 290 \\
\hline E1 & 0.6 & 25 & 14 & 100 & 60 \\
\hline E2 & 0.3 & 11 & 13 & 90 & 40 \\
\hline $2 \mathrm{Bt} 1$ & 0.3 & 3 & 9 & 120 & 60 \\
\hline $2 \mathrm{Bt} 2$ & 0.3 & 10 & 9 & 100 & 110 \\
\hline $2 \mathrm{Bt} 3$ & 0.3 & 3 & 14 & 110 & 80 \\
\hline $2 \mathrm{Bt} 4$ & 0.4 & 3 & 5 & 110 & 70 \\
\hline \multicolumn{6}{|l|}{ Rueter } \\
\hline A & 8.1 & 28 & 9 & 220 & 180 \\
\hline E & 3.5 & 35 & 7 & 120 & 50 \\
\hline Bt1 & 1.1 & 7 & 36 & 120 & 40 \\
\hline $2 \mathrm{Bt} 2$ & 0.8 & 5 & 15 & 130 & 40 \\
\hline $2 \mathrm{Bt} 3$ & 0.7 & 11 & 9 & 150 & 50 \\
\hline
\end{tabular}

$\mathrm{P}$ Bray-1 is phoshorus extraction, $2 \mathrm{M} \mathrm{KCl}$ is sulfate extraction; $\mathrm{AR}$ is an aqua regia digestion. 
$20 \%$ to $70 \%$ cherty fragments (gravel and cobbles) with the $2 \mathrm{Bt} 2$ and $2 \mathrm{Bt} 3$ horizons having appreciably more fragmental material. Weak and moderate fine subangular blocky structures in the near surface horizons transition to moderate fine subangular blocky structures in the deeper portions of the soil profile. The dominant soil matrix colors are brown and pale brown in the $\mathrm{A}$ and $\mathrm{E}$ horizons, transitioning to strong brown and yellowish red in the $2 \mathrm{Bt}$ horizons. The near surface horizons have an abundance of fine and very fine roots, whereas the deeper argillic horizon has less than one percent fine root expression.

Soil $\mathrm{pH}$ ranges from acidic to strongly acidic in the near-surface horizons and very strongly acidic to extremely acidic in the argillic horizon. The soil organic matter contents are generally moderate and decline with increasing soil depth. The exchangeable cations are dominated by calcium (Ca), especially in the deeper soil horizons. The total acidity is appreciable, particularly in the deeper soil horizons. The CEC is low (less than $12 \mathrm{cmol} \cdot \mathrm{kg}^{-1}$ ) in the eluvial horizons and medium $\left(12-18 \mathrm{cmol} \cdot \mathrm{kg}^{-1}\right)$ to low in the argillic horizon. Bray1-P and $\mathrm{SO}_{4}$-S concentration distributions show an accumulation in the eluvial horizons.

$\mathrm{X}$-ray diffraction of the whole clay separate of the Alred and Rueter pedons reveal that hydroxy-Al interlayered vermiculite and kaolinite are the dominant phyllosilicates with hydrous mica occurring as a secondary phyllosilicate. Mineral abundance determinations from X-ray diffractograms is a function of both phyllosilicate abundance and crystallinity, thus phyllosilicate abundance remains a qualitative assessment.

The aqua regia digestion was performed to assess the near total elemental content for each soil horizon. The aqua regia digestion of $\mathrm{P}$ and $\mathrm{S}$ (Table 8(b)) show a maximum in the A horizons with a smaller and relatively uniform distribution with increasing soil profile depth. The corresponding Bray-1 $\mathrm{P}$ for $\mathrm{H}_{2} \mathrm{PO}_{4}$ and the $2 \mathrm{M} \mathrm{KCl}$ extraction for $\mathrm{SO}_{4}$-S also demonstrate maximum concentrations in the A horizons; however, the recovered concentrations are much smaller than those of the aqua regia digestion. The soil organic matter contents show significant correlation with Bray-1 $\mathrm{P}(\mathrm{r}=0.8)$ and $\mathrm{P}$ aqua regia digestion $(\mathrm{r}$ $=0.91)$ values, whereas the soil organic matter content correlation with the aqua regia digestion sulfur $(r=0.84)$ is significant. Both $P$ and $S$ have an appreciable affinity for Fe-oxyhydroxide adsorption or occlusion. Thus, biocycling appears to be an important soil forming factor in A horizon nutrient enrichment.

The aqua regia digestion iron concentrations range from 9400 to 35,300 $\mathrm{mg} \cdot \mathrm{kg}^{-1}$ for the Alred pedon and range from 9600 to $26,000 \mathrm{mg} \cdot \mathrm{kg}^{-1}$ for the Rueter pedon (Table 9). For the combined Alred and Rueter pedons the aqua regia digestion iron content is significantly correlated with the clay content $(r=0.98)$. Most of the $\mathrm{Fe}$ is presumed to be $\mathrm{Fe}$ oxyhydroxides adsorbed onto the external clay surfaces and occluded with $\mathrm{Al}$ in clay interlayer positions. The iron aqua regia digestion concentrations demonstrated a significant correlation with the aluminum aqua regia digestion concentrations $(r=0.97)$, reflecting the prospect that the recovered aluminum and iron were associated with degraded phyllosilicates. 
Table 9. Aqua regia digestion of aluminum and selected transition metals.

\begin{tabular}{cccccccc}
\hline \multirow{2}{*}{ Horizon } & $\mathrm{Al}$ & $\mathrm{Fe}$ & $\mathrm{Mn}$ & $\mathrm{Co}$ & $\mathrm{Ni}$ & $\mathrm{Cu}$ & $\mathrm{Zn}$ \\
\cline { 2 - 8 } & & & $\mathrm{mg} / \mathrm{kg}$ & & & \\
\hline Alred & & & & & & & \\
A & 7200 & 9400 & 611 & 4.6 & 7.7 & 4.75 & 33 \\
E1 & 7400 & 10,400 & 341 & 5.6 & 13.3 & 4.34 & 24.8 \\
E2 & 12,000 & 13,300 & 122 & 8.6 & 10.5 & 6.56 & 31.6 \\
2Bt1 & 36,300 & 33,700 & 84 & 6.3 & 30.7 & 16.6 & 96.3 \\
2Bt2 & 46,200 & 34,900 & 73 & 6.3 & 34.5 & 16.4 & 114 \\
2Bt3 & 40,200 & 35,300 & 114 & 17.2 & 43 & 16.9 & 128 \\
2Bt4 & 41,500 & 34,000 & 253 & 11.2 & 48.4 & 17.5 & 139 \\
Rueter & & & & & & & \\
A & 6900 & 9600 & 325 & 3.3 & 6.7 & 4.4 & 27.3 \\
E & 8300 & 11,700 & 111 & 3.4 & 7.7 & 5.3 & 23.1 \\
Bt1 & 12,500 & 15,700 & 99 & 5 & 10.1 & 8.69 & 30.6 \\
2Bt2 & 23,100 & 26,000 & 103 & 6.3 & 16 & 14.1 & 49.8 \\
2Bt3 & 17,000 & 20,500 & 103 & 6 & 14.8 & 12.3 & 43.6 \\
\hline
\end{tabular}

For the combined Alred and Rueter pedons, the clay content is significantly correlated with $\mathrm{Ni}(\mathrm{r}=0.96), \mathrm{Cu}(\mathrm{r}=0.94)$ and $\mathrm{Zn}(\mathrm{r}=0.98)$.

Aqua regia digestion of important alkali and alkaline earth elements shows significant correlation with clay content: $\mathrm{K}(\mathrm{r}=0.97), \mathrm{Mg}(\mathrm{r}=0.98)$ and $\mathrm{Ca}(\mathrm{r}=$ 0.79). Lithium, $\mathrm{Rb}$, and $\mathrm{Cs}$ show similar trends as $\mathrm{K}$ with respect to clay content abundance. Strontium and $\mathrm{Ba}$ show similar trends as $\mathrm{Mg}$ and $\mathrm{Ca}$ with respect to clay content. Given that the aqua regia digestion $\mathrm{K}$ and $\mathrm{Mg}$ concentrations are much greater than the $\mathrm{K}$ and $\mathrm{Mg}$ exchangeable cation concentrations, most of these elements are associated as lattice constituents of phyllosilicates and primary minerals that are only marginally digested by the aqua regia digestion protocol (Table 10).

\subsection{Rare Earth Element Signature Profiles}

Rare earth elements (REE) are the elements of the Lanthanide Series of the Periodic Table and are characterized as having partially filled d orbitals. Most rare earth elements are trivalent species; however, Ce may have a tetravalent valence in oxidized soil environments and Eu may have divalent status in igneous rock lattice positions. The rare earth elements have been partitioned as the light REE (La to $\mathrm{Eu}$ ) and heavy REE (Gd to $\mathrm{Lu}$ ). In igneous rocks, the light and heavy REE's may reside in the lattice structure of different minerals, with apatite being a frequent mineral having light REE's and zircon being a frequent mineral having heavy REE's (Aide, 2020). Given that soils may have an array of various REE-bearing minerals and that these minerals may have variable REE isomorphic substitution, 
Table 10. Aqua regia digestion of alkali and alkaline earth metals.

\begin{tabular}{ccccc}
\hline \multirow{2}{*}{ Horizon } & Na & K & Mg & Ca \\
\cline { 2 - 5 } Alred & & & $\mathrm{mg} / \mathrm{kg}$ & \\
A & 240 & 900 & 700 & 2500 \\
E1 & 220 & 900 & 600 & 600 \\
E2 & 220 & 1500 & 1000 & 500 \\
2Bt1 & 130 & 3400 & 3500 & 2200 \\
2Bt2 & 230 & 5000 & 4700 & 2900 \\
2Bt3 & 200 & 4400 & 4500 & 3500 \\
2Bt4 & 230 & 5700 & 5300 & 3800 \\
Rueter & & & & \\
A & 200 & 700 & 600 & 1100 \\
E & 150 & 800 & 700 & 400 \\
Bt1 & 200 & 1000 & 1100 & 400 \\
2Bt2 & 180 & 1800 & 2300 & 600 \\
2Bt3 & 180 & 1800 & 1600 & 700 \\
\hline
\end{tabular}

the amount of the various REE's ranging from La to Lu may have different concentration patterns for different parent materials.

Upon mineral weathering, the REE's may undergo 1) hydrolysis, 2) complexation, especially as carbonates and as organic materials, and 3) adsorption on various substrates, especially phyllosilicates and Fe-oxyhydroxides. Thus, within various horizons of a soil profile the REEs may be viewed collectively having a signature pattern that may be compared among the soil horizons to isolate parent material differences or detect the activity of soil forming processes. The aqua regia digestion rare earth element recoveries from the 4) eluvial horizons (mean values of A, E, BE horizons in Figure 1) and the 2) illuvial horizons (mean values of the Bt horizons in Figure 2) show their REE signature patterns. The REE signature patterns for the Menfro, Alred and Rueter pedons exhibit a substantially greater abundance of the light rare earth elements, suggesting an over-all greater light REE abundance and a greater digestion efficiency for the aqua regia digestion protocol. The REE signature patterns spanning La to $\mathrm{Lu}$ are very similar among the Menfro, Alred and Rueter pedons, especially for the eluvial horizons. In general, the illuvial horizons, especially for the Alred pedon, have greater REE concentration recoveries, reflecting REE-bearing mineral weathering and subsequent adsorption on phyllosilicates and co-adsorbed Fe-oxyhydroxides. The similarity of the REE signature patterns supports Peoria Loess as an important parent material in each soil series, including the argillic horizons of the Alred and $\mathrm{Ru}-$ eter pedons. Thus, loess incorporation in the illuvial horizons of the Alred and Rueter pedons because of mass wasting and illuviation must be considered. 


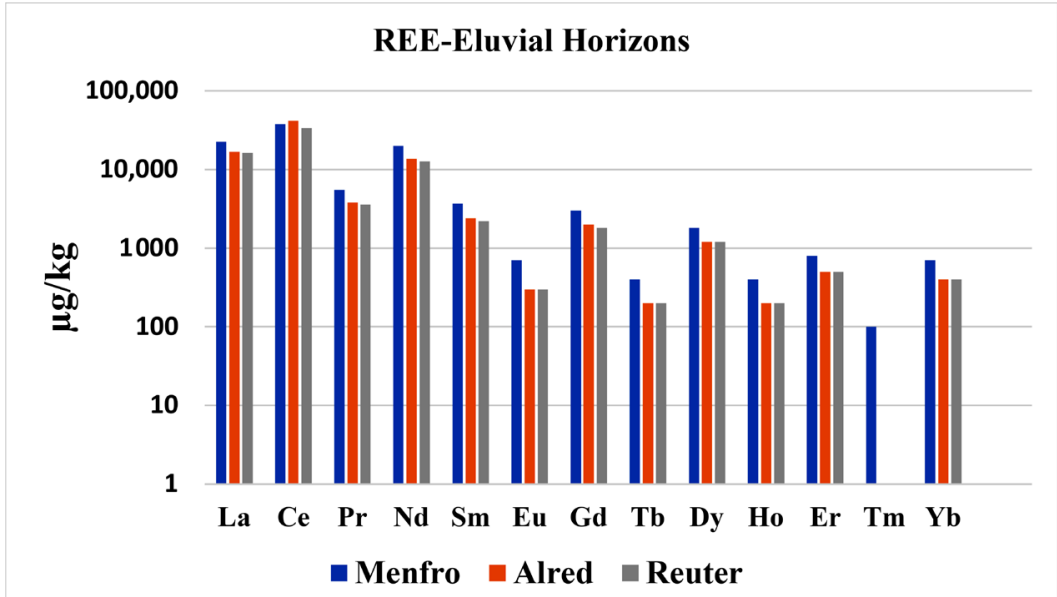

Figure 1. The rare earth element distribution for the mean of the eluvial horizons for the Menfro, Alred and Rueter pedons.

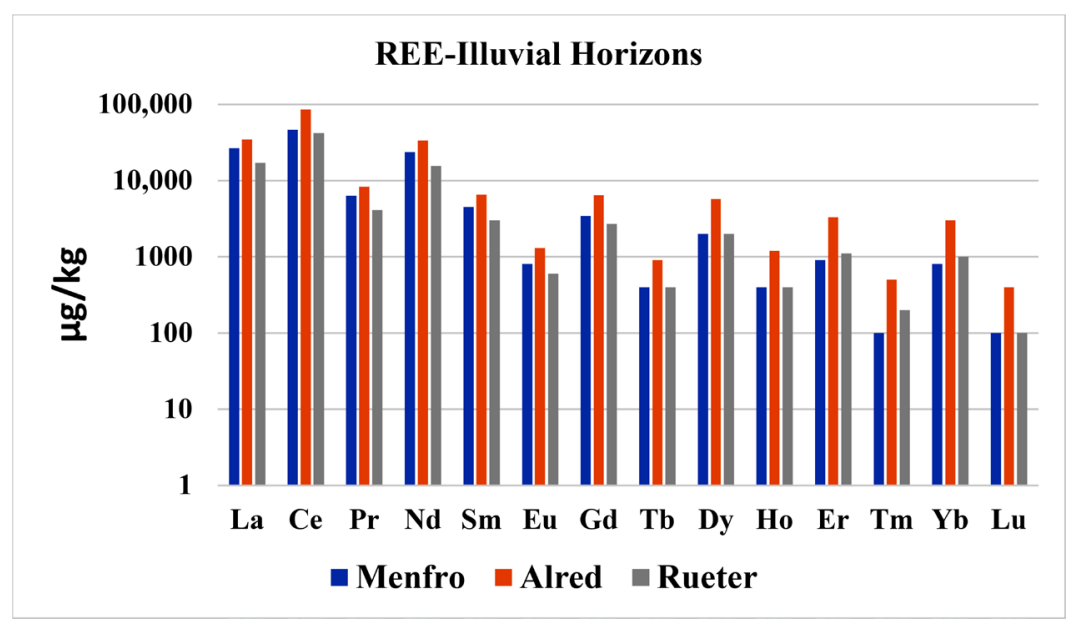

Figure 2. The rare earth element distribution for the mean of the illuvial horizons for the Menfro, Alred and Rueter pedons.

\section{Soil Genesis}

A key objective of this investigation is to identify and quantify active and ancestral soil forming processes that are representative of Alfisols across eastern Missouri. The dominant geologic influences across the study area include: (i) weathering of Paleozoic carbonate rocks and the release of entrained clastics, (ii) eolian deposition (including paleo-deposition or loess accumulation), and (iii) various forms of mass wasting and erosion. Mass wasting in the study area is indicated by the following features: 1) talus piles and isolated boulders resting at the soil surface, 2) cobbly and gravelly soil textures in soils having side or footslope positions, and 3) cobble and gravel soil profile differences. Soil creep is an understated form of mass wasting that frequently occurs on steeply sloping areas, particularly areas having intense rainfall and freeze-thaw cycles. Menfro soils on steeper slopes along incised drainages are shallower, as revealed by occasional rock outcrops. 


\subsection{The Influence of Climate}

The present climate is continental humid, with long hot summers with short moderate winters. Missouri July maximum temperatures range from $27^{\circ} \mathrm{C}$ to $34^{\circ} \mathrm{C}$, with abundant July clear sky daily solar radiation values ranging from 17 to $28 \mathrm{MJ} \cdot \mathrm{m}^{-2}$. The paleoclimate since the beginning of the Holocene witnessed a gradual transition from tundra to boreal forest to temperate deciduous forests (Royall et al., 1991).

\subsection{The Influence of Pedogenic and Geologic Processes}

A case for an eolian origin of the parent material in the sampled pedons includes: 1) sufficient landscape stability to support thick Peoria Loess accumulation in the Menfro pedons and mass wasting processes that limit partially the Peoria Loess preservation in the Alred and Rueter pedons, 2) loess deposition was an active process across the study area, and 3) the clay mineralogy of the eluvial and illuvial horizons shows consistency with Peoria Loess.

Previous research in the eastern Ozarks of Missouri involving soils developed in loess overlying limestone residuum have revealed lithologic discontinuities and parent material differences. Soil horizons developed in loess typically have a mixed mineralogy composed of smectite, HIM (hydroxyl-Al interlayered minerals (1.4 nm vermiculite)), hydrous mica, and kaolinite, whereas soil horizons developed in limestone residuum typically are kaolinitic (Aide and Marshaus, 2002; Aide, 2009). Bettis et al. (2003) documented that the Peoria Loess was deposited during the last glacial maximum in North America and is likely the thickest loess material, with the fastest mass accumulation rates, for any loess material. The clay mineralogy of the Peoria Loess along the Mississippi River in Missouri has a typical phyllosilicate distribution composed of kaolinite (3\% $11 \%)$, hydrous mica $(15 \%-24 \%)$, interstratified expandable associations (35\% $52 \%)$, vermiculite $(27 \%-52 \%)$ and smectite $(3 \%-29 \%)$.

Documenting the presence of a loess mantle is inherently difficult because haploidization and mass wasting processes, as well as the entrained clay minerals from the weathering of carbonate rocks contribute kaolinite which is also present in weathered loess. The REE recovery from the whole soil aqua regia digestion supports loess as a parent material that was initially incorporated by mass wasting and subsequently by eluviation-illuviation across indicated lithologic discontinuities in the Alred and Rueter pedons.

Based on soil morphology, the dominant soil forming processes include: 1) congruent and incongruent parent material weathering, 2) soil organic matter accumulation, 3) forest tree and understory elemental biocycling, 4) clay eluviation-illuviation, 5) soil acidification, 6) Fe-oxyhydroxide formation and adsorption onto phyllosilicates, and 7) nutrient leaching within and from the solum. The formation of the ochric epipedons and the underlying argillic horizons are coupled. Argillic horizon development requires the removal of any initial calcium carbonate, usually attributed to acidification and leaching, to permit sub- 
sequent clay and silt dispersion and lessivage. The eluviation-illuviation process requires a lengthy time interval, inferring the necessity of a relatively stable landscape. The mass wasting observed in the Alred and Rueter pedons likely occurred previous or concurrent with Peoria Loess deposition, otherwise the ochric epipedon-argillic horizon sequence would have been degraded.

No mass wasting was observed on the ridgetop positions associated with the Menfro pedons. The grayish silt flows in the deeper Bt horizons of the Menfro pedons reflect seasonal water saturation and cyclic oxidation-reduction of Feoxyhydroxides, resulting in soil aggregate dispersion, acidification, and silt migration (Hall et al., 2016; Fuss et al, 2010).

\subsection{Forest Vegetation Influencing Soil Development}

In this manuscript only forest vegetation influences are discussed; however, undoubtedly microbial, and heterotrophic influences are involved, and their activities are complex and influential. The accumulation of soil organic matter, especially in the A horizons results from well understood forest-soil interactions (Elliott et al., 2015; Groffman et al., 2009; Cheng and Kuzyakov, 2005; Fahey et al., 2005; Fujinuma et al., 2005; Treseder et al., 2005; Federer, 1984). Forest tree biocycling is evident by the soil profile distribution of the exchangeable cations, soil test values for phosphate and sulfate, and the aqua regia digestion values for manganese, phosphate, and sulfate. The net primary production of the forest and understory vegetation supports cation and anion uptake patterns responsible for A horizon nutrient enrichment (Elliott et al., 2015; Fujinuma et al., 2005; Groffman et al., 2009; Federer, 1984). The litter layers resting on the soil and incorporated partially into the A horizons are coupled in the process of carbon accumulation and humus formation, involving an array of heterotrophic and microbial community. The root rhizosphere is undoubtedly instrumental in soil acidification and nutrient uptake (Cheng and Kuzyakov, 2005; Treseder et al., 2005).

The presence of prominent argillic horizons substantiates clay eluviation-illuviation as an important soil forming processes. Similarly, the Fe-oxyhydroxide concentrations and low $\mathrm{pH}$ levels are predictable soil properties arising from long-term weathering in a continental humid climate (Buol et al., 2003). One question that remains to be evaluated is whether Fe-oxyhydroxides associated with the clay separate were co-illuviated with the phyllosilicates or were synthesized and adsorbed within the argillic horizon.

\section{Best Management Interpretations}

Because of the risk associated with erosion and based on the USDA land capability classification criteria (USDA-Soil Conservation Service, 1961), these soils should be limited to forest growth. Currently, both study areas are associated with state-managed conservation areas; however, limited land capability applies to similar soil types having similar ecological site descriptions. For the Juden 
Creek Conservation Area having the Menfro soil sites, the ecological site descriptions specify land management practices that shift the prevailing vegetation community from the reference state to 1) an uneven-age managed forest with preponderance of Northern Red Oak (Quercus rubra), 2) and even-age managed forest with preponderance of White Oak (Quercus alba), 3) a high graded, grazed forest with preponderance of hickory (Carya)-white ash (Fraxinus americana), or 4) grassland. Similar land management practices that shift the prevailing reference vegetation are specified for the Apple Creek Conservation Area containing the Alred and Rueter soils.

\section{Conclusion}

Four Alfisols were characterized and their dominant soil forming factors elucidated. Key soil forming factors included: 1) clay eluviation-illuviation, 2) soil organic matter accumulation, 3) soil acidification, 4) base cation accumulation in the A horizons, 5) the influence of mass wasting in two of the soil profiles, and 6) the role of Peoria Loess as a parent material. The emerging information platform of Ecological Site Descriptions was implemented to provide landowner abilities to make informed land management decisions to lessen deleterious outcomes involving ecosystem stability.

\section{Conflicts of Interest}

The author declares no conflicts of interest regarding the publication of this paper.

\section{References}

Aide, M. T. (2009). Three Missouri Alfisols Impacted by Aeolian Deposition of Pb-ZnCd-Ag Bearing Mine Tailings. Soil Sediment Contamination, 18, 43-54. https://doi.org/10.1080/15320380802545332

Aide, M. T. (2020). Review and Assessment of Organic and Inorganic Rare Earth Element Complexes in Soil, Surface Water, and Groundwater. In M. Aide, \& T. Nakajima (Eds.), Rare Earth Elements and their Minerals (pp. 3-20). London: IntechOpen. https://doi.org/10.5772/intechopen.87033

Aide, M. T., \& Fasnacht, M. (2010). Estimating Trace Element Availability in Soils Having a Seasonal Water Table Using Commercially Available Protocols. Communications in Soil Science and Plant Analysis, 41, 1159-1177. https://doi.org/10.1080/00103621003721379

Aide, M. T., \& Marshaus, A. (2002). Fragipan Genesis in Two Alfisols in East Central Missouri. Soil Science, 167, 453-464. https://doi.org/10.1097/00010694-200207000-00004

Bettis, E. A., Muhs, D. R., Roberts, H. M., \& Wintle, A. G. (2003). Last Glacial Loess in the Conterminous USA. USGS Staff-Published Research. Quaternary Science Reviews, 22, 1907-1946. https://digitalcommons.unl.edu/usgsstaffpub/180 https://doi.org/10.1016/S0277-3791(03)00169-0

Buol, S. W., Southard, R. J., Graham, R. C., \& McDaniel, P. A. (2003). Soil Genesis and Classification. Ames, IA: Iowa State Press. 
Carter, M. R. (1993). Soil Sampling and Methods of Analysis. Boca Raton, FL: Lewis Publ.

Cheng, W., \& Kuzyakov, Y. (2005). Root Effects on Soil Organic Matter Decomposition. In R. W. Zobel, \& S. F. Wright (Eds.), Roots and Soil Management: Interactions between Roots and the Soil (pp. 119-144). Agronomy Monograph No. 48, Madison, WI: American Society Agronomy. https://doi.org/10.2134/agronmonogr48.c7

Elliott, K. J., Vose, J. M., Knoepp, J. D., Clinton, B. D., \& Kloeppel, B. D. (2015). Functional Role of the Herbaceous Layer in Eastern Deciduous Forest Ecosystems. Ecosystems, 18, 221-236. https://doi.org/10.1007/s10021-014-9825-x

Fahey, T. J., Siccama, T. G., Driscoll, C. T., Likens, G. E., Campbell, J., Johnson, C. E., Battles, J. J., Aber, J. D., Cole, J. J., Fisk, M. C., Groffman, P. M., Hamburg, S. P., Holmes, R. T., Schwartz, P. A., \& Yanai, R. D. (2005). The Biogeochemistry of Carbon at Hubbard Brook. Biochemistry, 75, 109-176.

https://doi.org/10.1007/s10533-004-6321-y

Federer, C. A. (1984). Organic-Matter and Nitrogen-Content of the Forest Floor in Even-Aged Northern Hardwoods. Canadian Journal of Forest Research, 14, 763-767. https://doi.org/10.1139/x84-136

Fujinuma, R., Bockheim, J., \& Balster, N. (2005). Base-Cation Cycling by Individual Tree Species in Old-Growth Forests of Upper Michigan, USA. Biogeochemistry, 74, 357-376. https://doi.org/10.1007/s10533-004-4726-2

Fuss, C. B., Driscoll, C. T., \& Johnson, C. E. (2010). Dynamics of Oxidized and Reduced Iron in a Northern Hardwood Forest. Biogeochemistry, 104, 103-119. https://doi.org/10.1007/s10533-010-9490-x

Groffman, P. M., Hardy, J. P., Fisk, M. C., Fahey, T. J., \& Driscoll, C. T. (2009). Climate Variation and Soil Carbon and Nitrogen Cycling Processes in a Northern Hardwood Forest. Ecosystems, 12, 927-943. https://doi.org/10.1007/s10021-009-9268-y

Hall, S. J., Liptzin, D., Buss, H. L., DeAngelis, K., \& Silver, W. L. (2016). Drivers and Patterns of Iron Redox Cycling from Surface to Bedrock in a Deep Tropical Forest Soil: A New Conceptual Model. Biogeochemistry, 130, 177-190. https://doi.org/10.1007/s10533-016-0251-3

Moore, D. M., \& Reynolds, R. C. (1989). X-Ray Diffraction and the Identification and Analysis of Clay Minerals. Oxford: Oxford University Press.

Royall, P. D., Delcourt, P. A., \& Delcourt, H. R. (1991). Late Quaternary Paleoecology and Paleoenvironments of the Central Mississippi Alluvial Valley. Geological Society of America Bulletin, 103, 157-170. https://doi.org/10.1130/0016-7606(1991)103<0157:LQPAPO>2.3.CO;2

Soil Conservation Service (1961). Land-Capability Classification. USDA Handbook 210, Washington DC: U.S. Gov. Print Office. https://www.nrcs.usda.gov/Internet/FSE_DOCUMENTS/nrcs142p2_052290.pdf

Soil Survey Division Staff (1993). Soil Survey Manual. USDA Handbook 18, Washington DC: U.S. Gov. Print Office.

Soil Survey Staff (2014). Keys to Soil Taxonomy (12th ed.). Washington DC: USDA-Natural Resources Conservation Service.

Treseder, K. K., Morris, S. J., \& Allen, M. F. (2005). The Contributions of Root Exudates, Symbionts, and Detritus to Carbon Sequestration in the Soil. In R. W. Zobel, \& S. F. Wright (Eds.), Roots and Soil Management: Interactions between Roots and the Soil (pp. 145-162). Agronomy Monograph No. 48, Madison, WI: American Society Agronomy. https://doi.org/10.2134/agronmonogr48.c8 